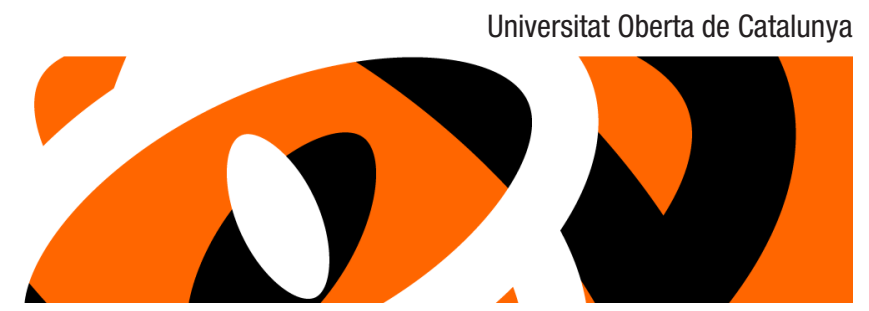

http://artnodes.uoc.edu

\title{
Art and education: the need for an uneasy meeting of fields that question each other
}

\author{
Aida Sánchez de Serdio Martín \\ Public and Education Advisor at the Museo Nacional Centro de Arte Reina Sofía, \\ Madrid and at the UOC
}

Published in: June 2016

This edition of Artnodes is devoted to the relationships between art and education, with the definition of the space connecting both terms intentionally left open, given that it is currently constituted in very different ways. Definitively questioning the idea that education is a vehicle to convey cultural content-or in other words, a domain that reproduces another field that is productive-, art and education hybridise to provide all types of overlaps in which neither is instrumental for the other, rather that they generate unexpected and inseparable forms of creation and learning.

However, if this overlapping of art and education is productive, it is also because both mutually challenge and question each other. Education questions art, shifting its dominantly disciplinary readings, relating it to other subjectivities, social contexts, and political debates, and becoming a space of cultural production and creativity in its own right. Artistic practice also pushes the traditional boundaries of knowledge production and transfer, exploring the uncertainty of meaning and methodological heterodoxy, whilst questioning the established forms of scientific validity.

Ideas such as educational turn, mediation, performativity, artistic research, institutional critique, etc. have started to circulate about the connections between education and art, providing new layers of complexity to this relationship, and placing it at the centre of current cultural debates. ${ }^{1}$ However, those concepts aren't just there to celebrate the positive or affirmative possibilities deriving from the relationships between art and education. Above all, they create new spaces for debate and practice, which also have their own tensions and contradictions. The purpose of this edition is precisely to collect and relate contributions that explore those spaces through theoretical debates and discussions about practical examples.

The articles published here share a conception of the fields of art and education as domains in transformation, either as a product of how they overlap, or of the independent crises they are currently experiencing. They also indicate similar movements in both fields, which are bringing them closer, favouring overlaps that, as we said, are never without tensions. However, this encounter enables emancipatory possibilities to emerge given the fact that the hybridisation is located at the core of political debates in which the production of new subjectivities and shared ways of living are at stake. In this sense, a term that has taken on a significant role in the educational domain when designating this hybrid space is that of the "educational turn", which initially came from the artistic and curatorial domains. We will see how the authors examine this turn in different ways, oscillating between confidence in its possibilities and criticism of its paradoxical effect of downgrading the educational field.

1. The fact that a journal such as Artnodes, which is essentially focused on how art, science, and technology overlap, dedicates a special edition to this topic is in itself an example of this new central role education has acquired in the artistic domain. 


\section{artnodes}

http://artnodes.uoc.edu

As such, in their article, "Aguas turbulentas: el encuentro entre el giro educativo en el arte y el giro de la visualidad en la educación ('Turbulent waters: the overlap of the educational turn in art and the visuality turn in education'), Tatiana Fernández and Belidson Dias demonstrate a dual movement: the pictorial turn in education and the educational turn in art. The former, albeit still uncommon, takes the pictorial turn proposed by W. J. T. Mitchell as a space, not simply to include images in teaching, but specifically to question the modes of production of knowledge, subjectivity, and difference in education. The authors indicate Visual Culture education as one of the trends developing this ideas and opening up practical possibilities. The educational turn would be a space that allows to work between the social value of art and the aesthetic value of education. Thus, it would be an artistic practice that questions the autonomy desired by modern art in favour of a heteronomy in which participants have a key role. The artistic event would therefore produce essential learning experiences, becoming pedagogy in itself. This has political, methodological, and existential implications that ultimately point to the differences in the construction of the identities of educators and artists (as well as researchers or students). These identities are marked by historical and structural differences, but they face similar contradictions and challenges in terms of their political responsibility in an emancipatory project.

Sergio Martínez Luna' article, "Entre-en-medios del arte y la educación: colaboraciones, experimentalismo, interdisciplinariedad" ('The in-betweenness of art and education: collaborations, experimentalism, and interdisciplinarity'), proposes that the overlaps between art and education are complex given the crises existing in both concepts. A crisis that is also an opportunity to open up to their mutual differences and explore other ways of reflection and practice. It wouldn't be just a question of re-affirming the original fields, but rather of recognising interdisciplinarity and the spaces between them or their contact zones, as the place where hybridisations emerge that challenge dual conceptions. The author sees the loss of autonomy or narrative in both fields as productive to some extent (the art crisis involves the production of consumer objects and the institutional transgression-assimilation dynamic. The educational crisis involves its paradigmatic identification with the educational institution, and employability as the target objective). These types of experiences would relate with Laddaga's democratic experimentalism concept, which looks for alternatives to representative democracy, and in terms of artistic practices, this would be a commitment to the democratisation of its representations, mediations, and resources. As an example of this overlapping of critical and collective pedagogies with collaborative artistic practices, Martínez analyses the "Neither art nor education project" developed by the Grupo de Pensamiento de Educación Disruptiva of Matadero Madrid.

Bringing a critical viewpoint of the so-called "educational turn", Fermín Soria's article, "Tensiones, paradojas, debates terminológicos y algunas posibilidades transformadoras en el marco del giro educativo en los proyectos artísticos y el comisariado" ('Tensions, paradoxes, terminological debates, and some transformative possibilities within the educational turn framework in artistic and curatorial projects'), begins by debating the neoliberal capture of education and art. In this context, the relationships between both fields have to oscillate between contradiction and possibility. The author indicates how artistic and curatorial practices that often adopt educational paradigms do so on the basis of the paradoxical rejection of an education considered repetitive, transmissive, or authoritarian (which applies to its agents, educators, by extension). In addition, these radical proposals run the risk of ending up targeting a homogeneous audience that share the same cultural capital and references as curators and artists, in such a way that their transformative capacity is limited and easily absorbed by the art establishment. Conversely, however, Soria maintains that the educational turn is also a space for possible transversal collaborations between educators, curators, artists, and other agents. These relationships aren't necessarily fluid, but rather marked by conflicts and internal antagonisms, as well as being conditioned by their own institutional limits and power relationships. However, and with no pretensions of removing such contradictions, it would be possible to consider those overlaps as contact zones or hybridisation areas from where transformative practices could be proposed and activated.

In his article, "El Cinefòrum Poble Sec como 'escuela' de lo común: dispositivo situado frente a modos de direccionalidad" ('Cinefòrum Poble Sec as a 'school' for the common: situated device versus modes of address'), Aurelio Castro introduces film technology into the debate, and proposes it as a device, taking the same approach as Foucault and Agamben, i.e. as a network of discourses, practices, mechanisms, regulations, and institutions. The author puts forward a relationship between education and film that goes from historical examples such as the Pedagogic Missions in Spain in the 1930s, up to citing the current case of the Cinefòrum of the Poble Sec Assembly in Barcelona. In the first case, the projection room is related to the classroom, and the film narrative to a class, thus producing a pedagogy through sounds and images that would aspire to teach children and adults to see so that spectator autonomy can be created, linked to the production of an alternative public sphere, and ultimately, social transformation. Authors such as Elizabeth Ellsworth have questioned this confidence in the possibility of communicative dialogue, arguing that this coincidental meeting between film and the spectator is always impossible given that they never occupy the role presupposed by the film narrative's address. However, the author also questions this perspective, proposing that the Cineforrum of the Poble Sec Assembly activated a complex projection device linked with an assembly practice that was grounded in a corporeal politics of care and shared precariousness, rather than positional and social differences, and therefore constituting a film pedagogy. 


\section{artnodes}

http://artnodes.uoc.edu

Lastly, in "El arte y su educación en la era de la hipermediación digital" ('Art and art education in the era of digital hypermediation'), Ricardo González García tackles the need to rethink the relationships between art and education within a context in which digital technologies strongly mediate our experience in both fields. The prosumer emerges to counter the mass culture passive receptor spectator, adopting an active role in receiving and producing the images that digital technologies spread. Artistic practice appears to be deeply affected by this saturation of ever-changing and hybrid images. In addition, school and traditional educational models are entering a crisis, opening up to the interdisciplinarity and instability of knowledge, and social collaboration, with digital illiteracy understood
Art and education: the need for an uneasy meeting of fields that question each other

\section{Recommended reading}

SÁNCHEZ DE SERDIO MARTíN, Aida (2016). "Art and education: the need for an uneasy meeting of fields that question each other." In: "Art and education" [online node]. Artnodes, no. 17,pp. 2-5. UOC. [Accessed: dd/mm/yy] $<$ http://journals.uoc.edu/ojs/index.php/artnodes/article/view/n17-sanchez/n17-sanchez-pdf-en> <http://dx.doi.org/10.7238/a.v0i17.3012>>

\footnotetext{
Els textos publicats en aquesta revista estan subjectes -llevat que s'indiqui el contrari- a una llicència de Reconeixement-Sense obres derivades 3.0 Espanya de Creative Commons. Podeu copiar-Ios, distribuir-los i transmetre'Is públicament sempre que citeu l'autor, la revista i la institució que els publica (IDP. Revista d'Internet, Dret i Política; UOC); no en feu obres derivades. La llicència completa es
} pot consultar a http://creativecommons.org/licenses/by-nd/3.0/es/deed.ca. 


\section{artnodes}

http://artnodes.uoc.edu

Art and education: the need for an uneasy meeting of fields that question each other

\section{About the author}

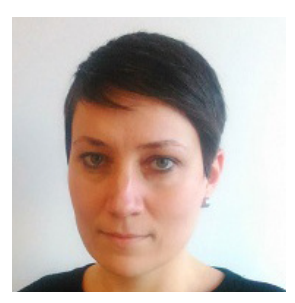

\section{Aida Sánchez de Serdio Martín}

Public and Education Advisor at the Museo Nacional Centro de Arte Reina Sofía, Madrid and at the Open University of Catalonia sanchezdeserdio@gmail.com

Aida Sánchez de Serdio Martín is a cultural worker, researcher, and educator in the fields of visual culture, education, and collaborative artistic practices. She is currently Public and Education advisor for both the Museo Nacional Centro de Arte Reina Sofía in Madrid and the Open University of Catalonia. She has a doctorate in Fine Arts and was a lecturer in both the Cultural Pedagogy Unit of the Fine Arts Faculty of the University of Barcelona from 1998 to 2014, and the Faculty of Architecture of the University of Umeå (Sweden) from 2014 to 2015. She is also a lecturer for the official master's degree, "Visual arts and education, a constructionist approach" and the doctorate programme, "Arts and education", in addition to forming part of the research group, "Esbrina - subjectivity and contemporaneous educational domains", all in the University of Barcelona. She has been a visiting lecturer in the University of Lisbon, Goldsmiths College (London), the University of the Republic (Uruguay), and Zürcher Hochschule der Künste (Switzerland), among others. She has written numerous articles and chapters in books on the connections between art, education, and visual culture. She has also been involved or collaborated on educational and cultural projects such as la Asociación para jóvenes Teb, Artibarri, Prácticas Dialógicas (Museu Es Baluard, Palma de Mallorca), Transductores, Zones de Contacte (La Virreina Centre de la Imatge, Barcelona), Pedagogies de Fricció (Fundació Joan Miró), and Centre de Cultura de Dones Francesca Bonnemaison, etc

\section{$\bullet$ UOC \\ Universitat Oberta de Catalunya}

